\title{
Basosquamous Carcinoma of Skin in A Developing Community
}

\author{
Wilson I B Onuigbo* \\ Department of Pathology, Medical Foundation and Clinic, Nigeria
}

Submission: December 18, 2018; Published: January 08, 2019

*Corresponding author: Wilson IB Onuigbo, Department of Pathology, Medical Foundation and Clinic, 8, Nsukka Lane, Enugu 400001, Nigeria

\section{Abstract}

Recently, single case reports were published from India, Romania, UK, and USA. Its rarity was stressed as well as the histological combination of both basal cell carcinoma and squamous cell carcinoma. The ages ranged from 71 to 86 years and most were females. Therefore, this paper reports the experience from a developing community in Nigeria with special reference to members of the Ibo ethnic group in whom the site of preponderance was the head and the sex was the female.

Keywords: Skin; Cancer; Basosquamous carcinoma; Head; Sex; Developing community

\section{Introduction}

Recent single case reports appeared in the literature from India [1], Romania [2], UK [3], and USA [4]. Not only was its rarity stressed but also its combining of the histology of basal cell carcinoma and squamous cell carcinoma. Among the findings was the age group of 61 years to 86 years as well as the preponderance of female sufferers. Therefore, this paper sets out to present the findings among the Ibo ethnic group, of whom a British anthropologist wrote about copiously [5]. Moreover, there was the advantage that a Birmingham (UK) group proposed Results (Table 1)

Table 1: Epidemiological data on basosquamous carcinoma among lbos.

\begin{tabular}{|c|c|c|c|}
\hline No & Initials & Age & \\
\hline 1 & ZV & 18 & \\
\hline 2 & AC & 60 & \\
\hline 3 & IW & 48 & \\
\hline 4 & EE & 42 & \\
\hline 5 & ER & 58 & \\
\hline 6 & EM & 50 & \\
\hline 7 & OA & 40 & \\
\hline 8 & NC & 40 & \\
\hline 9 & NN & & \\
\hline
\end{tabular}

\section{Discussion}

Australian authors [8] defined basosquamous carcinoma as "a basal cell carcinoma (BCC) differentiating into squamous cell carcinoma (SCC)." I am persuaded that both features were present in the local cases. The local cohort consisted of 7 females out of a total of 9 cases. A Swiss paper bothered not with the sex incidence but with recurrence rate which was reported to be that the establishment of a histopathology data pool facilitates epidemiological analysis [6]. In this context, the author became the pioneer of such a pool established by the Government of the Eastern Region of Nigeria at Enugu. Moreover, he trained at the prestigious Glasgow Western Infirmary [7]. Therefore, having insisted on biopsies being sent with epidemiological data, and carefully keeping personal duplicates, the results in respect of basosquamous carcinoma of skin can be presented below in tabular form. 
2. Mercut R, Georgescu C, Popescu SM, Ciurea M, Scrieciu M, et al. (2014) Face basosquamous carcinoma: A case report. Curr Health Sci J 40(4): 277-280.

3. Anand RL, Collins D, Chapman A (2017) Basosquamous carcinoma: Appearance and reality. Oxf Med Case Reports: 2017(1) omw095.

4. Bisgaard E, Tarakji M, Lau F, Riker A (2016) Neglected skin cancer in the elderly: A case of basosquamous cell carcinoma of the right shoulder. J Surg Case Rep 2016(8): rjw134.

5. Basden GT, Celestine, Chukwuemeka, Mbaegbu (1996) The Effective Power of Music in Africa. Niger Ibos London: Frank Cass.

6. Macartney JC, Rollaston TP, Codling BW (1980) Use of a histopathology data pool for epidemiological analysis. J Clin Pathol 33(4): 351-353.

7. Jacyna LS (1988) The laboratory and the clinic: The impact of pathology on surgical diagnosis in the Glasgow Western Infirmary, 1875-1910. Bull Hist Med 62(3):384-406.

This work is licensed under Creative Commons Attribution 4.0 License

DOI: 10.19080/IJCSMB.2019.05.555664
8. Leibovitch I, Huilgol SC, Selva D, Paver R (2005) Basosquamous carcinoma: Treatment with Mohs micrographic surgery. Cancer 104(5): 170-175.

9. Skaria AM (2010) Recurrence of basosquamous carcinoma after Mohs micrographic surgery. Dermatology 221(4): 352-355.

10. Wermker K, Roknic N, Goessling K (2015) Basosquamous carcinoma of the head and neck: Clinical and histologic characteristics and their impact on disease progression123. Neoplasia 17(3): 301-305.

11. Bucci T, Santoro A, Pannone G (2016) Metastatic basosquamous carcinoma: Report of two cases and clinicopathological considerations. Int J Surg Pathol 24(8): 726-732.

12. Oldbury JW, Wain RAJ, Abas S, Christopher M Dobson, Srinivasan Iyer, et al. (2018) Basosquamous carcinoma: A single centre clinicopathological evaluation and proposal of an evidence-based protocol. J Skin Cancer.

\section{Your next submission with Juniper Publishers will reach you the below assets}

- Quality Editorial service

- Swift Peer Review

- Reprints availability

- E-prints Service

- Manuscript Podcast for convenient understanding

- Global attainment for your research

- Manuscript accessibility in different formats ( Pdf, E-pub, Full Text, Audio)

- Unceasing customer service

Track the below URL for one-step submission https://juniperpublishers.com/online-submission.php 